\title{
THOMAS DOVER AND THE SOUTH SEA COMPANY
}

by

\section{KENNETH DEWHURST* and REX DOUBLET**}

It is well known that Thomas Dover's career was one of the most colourful and varied of any British medical practitioner. He has been described erroneously as a "buccaneer", 1 a "mountebank" 2 and a "pirate on the Spanish Main": 3 all these labels do him ill justice and ignore the temper of his times. More accurately, he should be regarded as a "physician and merchant adventurer"," although the full extent of his ventures have not been fully revealed by his biographers.

In medical circles he is now remembered as a pupil of Thomas Sydenham, and the originator of "Dover's powder", although in his own day, he was better known as the peppery "Quicksilver Doctor" and author of the best-selling remedy book The ancient physician's legacy. But medicine was only one of his claims to notice. As a ship's captain Dover made several voyages to West Africa and the Caribbean in the early days of the slave trade. Later he helped to finance, and played a leading role, in the most successful privateering voyage in British maritime history: it was during this voyage round the world that Dover rescued Alexander Selkirk whose singular adventures, it is said, provided Defoe with the germ of truth which he swelled into the great romance of Robinson Crusoe. Later he sacked and ransomed the main Peruvian port of Guayaquil; but from a historical, rather than a medical point of view, one of the most important interludes in his long life was his pioneering of British commercial interests in South America as the first President of the South Sea Company's "factory" or trading post in Buenos Aires. This hitherto unrecorded dimension of his career will be treated here in some detail as it is based on manuscript material. But to preserve biographical continuity, the rest of his life has also been summarized. ${ }^{5}$

Thomas Dover had a distinguished though rebellious family history. His greatgrandfather, William Cole, sometime President of Corpus Christi College, Oxford, was expelled for his adherence to Protestantism, and thereafter lived in exile translating the Geneva Bible until Elizabeth I came to the throne. He eventually regained his college appointment, only to be dismissed for fraud. His grandfather, Robert Dover, a land-owning lawyer, had achieved local fame as the founder of the Cotswold games held annually in an arena, still known as Dover's Hill, near the old market town of Chipping Campden. John Dover (the doctor's father) served as a captain of horse under Prince Rupert during the Civil War, and afterwards farmed in melancholy retirement at Barton-on-the-Heath, near Moreton-in-Marsh, where Thomas was born in 1662.

We know little of his early life. He probably attended Chipping Campden Grammar School, and in 1680 entered Magdalen Hall, Oxford, as a commoner. It was not a

* The Manor House, Sandford-on-Thames, Oxford OX4 4YN.

** Dunstone, Dorrington, Shropshire.

Medical History, 1974, vol. 18. 


\section{Kenneth Dewhurst and Rex Doublet}

particularly distinguished period in Oxford medicine. There was a lull in the great upsurge of empirical enquiry as the brilliant founders of the Royal Society had forsaken Oxford for London, leaving only undistinguished "political" incumbents behind. Dover graduated B.A. in 1684, and then we lose sight of him until his admission to Caius College, Cambridge, two years later. He was probably serving a clinical apprenticeship to Dr. Thomas Sydenham, at whose home he contracted smallpox. Fifty years later, Dover gave a vivid account of his treatment. First, he was let twentytwo ounces of blood; and when blinded by the vesicular eruption, was put to bed with sheets no higher than his waist in an unheated room, and given a light diet of twelve bottles of beer acidulated with spirits of vitriol every twenty-four hours. This Spartan regimen brought about an uncomplicated recovery. His clinical apprenticeship completed, Dover spent a year in Cambridge, graduating bachelor of medicine in 1687. Shortly afterwards he married, and returned to his native Cotswolds; and on his father's death, inherited the family property: his elder brother John, being left only $£ 5$ "to buy him a mourning gowne", and his four sisters also received trivial recognition from the old cavalier.

Dover moved to Bristol, probably in 1691 and, four years later, was the first medical man to offer his services gratuitously to the sick poor of St. Peter's Hospital, a workhouse and asylum founded by John Carey to relieve poverty caused by the French war. Bristol, though the second city in the Kingdom, had few doctors. Forty years later there were only five physicians, nineteen surgeons, thirteen barber-surgeons and twenty-nine apothecaries: hence it is understandable that many citizens complained the "physicians came only to close the eyes and administer musk", so that their patients could die in a comforting odour of sanctity.

The basis of Bristol's prosperity was, of course, its maritime trade particularly with America and the West Indies. Abolition of the Africa Company's monopoly (favouring London merchants) had increased Bristol's slave trade, and in 1709 fifty-seven ships were constantly engaged in slaving. Merchandise was taken to West Africa, bartered for slaves, who were transported to the West Indies from whence vessels returned home laden with tropical commodities. Evidently Dover found that trading slaves to the West Indies was more profitable than treating patients in Bristol, as between 1701-1707 he made several Caribbean voyages probably as part-owner and ship's doctor, and later, with his increasing knowledge of navigation and seamanship, he probably commanded his own vessel. Henceforth he became known as Captain Dover among Bristol's seafaring fraternity; and in 1708 profits from these voyages enabled him to take a large share in fitting out two privateers while retaining his Cotswolds lands.

During the war of the Spanish Succession, British maritime policy had changed. In 1708, a new Prize Act permitted owners and crew of privateers to retain all prize money whereas previously the Crown had taken one-third. Thus, when Dover took a financial interest in privateering it was regarded by the Crown as a relatively cheap means of fighting the country's enemies. He joined a syndicate of Bristol merchants and city dignitaries (including the Lord Mayor, Sheriff, and Town Clerk) who contributed to fitting out an expedition to the South Seas: it was to be Bristol's reply to the foreign onslaught on her shipping. The commander, Woodes Rogers, was granted a 


\section{Thomas Dover and the South Sea Company}

commission by Prince George of Denmark (Consort to Queen Anne) and Lord High Admiral of Great Britain and Ireland, "to cruise on the coasts of Peru and Mexico, in the South Sea, against Her Majesty's enemies the French and Spaniards". 6 It was, therefore, a highly respectable expedition which Dover helped to finance. The cost of fitting out two frigates, the Duke and Dutchess, was $£ 15,000$. Thomas Goldney, a Quaker grocer, invested $£ 3,700$, Dover being the next largest shareholder, contributing $£ 3,000$, and, in order to safeguard his interest, he decided to join the expedition as the owners' representative.

Their adventures soon began. After leaving Cork for the Canary Isles the men mutinied, and officers prudently carried firearms until the danger subsided. In the Canaries they stocked up with liquor, as Rogers firmly believed that it was "preferable to clothing in withstanding the hazards off Cape Horn". After an uneventful passage across the South Atlantic, they battered their way through heavy seas off Cape Horn, and made more tranquil progress skirting the western coast of South America. Scurvy was now weakening the crew and Dover realized that a supply of fresh fruit and vegetables was urgently needed. Fortunately Captain William Dampier, the best navigator of his times, had joined the expedition as pilot, and his skill together with his previous experience in these waters brought them safely to anchor off the islands of Juan Fernandez. Dover took a pinnace ashore and returned "with a man clothed in goatskins who looked wilder than the first owners of them". ${ }^{7}$ He turned out to be Alexander Selkirk. A Scot, he had been stranded alone on the island for four years after a dispute with his captain. They took him aboard as sailing master. After overhauling and reprovisioning, the two frigates captured several small vessels off the coast of Chile. The British squadron, now comprising eight ships together with over 300 prisoners, decided to attack the town of Guayaquil, the largest ship-building port in Peru (now in Ecuador), and an assault party of 200 were embarked in the ship's boats to row the thirty-six miles upstream. Dover was appointed Commander-in-Chief of the attack. At midnight when they were abreast of the town, a blazing beacon gave the alarm. Dover then called off the assault, and sent an emissary to parley with the Governor. After two days of close haggling the Governor finally agreed to pay 40,000 pieces-of-eight, but he was only able to raise 30,000 . It was then that the British lost patience and attacked. They soon overcame superior Spanish forces, and ransacked the houses, but when they ransomed back the town they still got only 30,000 piecesof-eight.

While bound for the Galapagos Islands, 180 men were stricken with plague. Dover took charge, and his regimen of heroic bleeding and copious fluids kept down the mortality to ten. Indeed it is tribute to Dover's skill as chief medical officer that the whole expedition had less disruptions through sickness than any previous voyage round the world. Off the Californian coast they intercepted a rich prize which surrendered after a brisk engagement. A few days later a larger Spanish ship-the flagship of the fleet-was sighted, and a violent sea battle began. In spite of superior forces the British ships could not pierce the Spaniard's stout hull, and after two days of bitter fighting they were forced to disengage, suffering over thirty casualties and severe damage to all three ships. Soon afterwards Dover came into conflict with Rogers over the command of their largest prize, the Batchelor. It was eventually resolved that 


\section{Kenneth Dewhurst and Rex Doublet}

Dover should command the ship on the long voyage home via Guam, the Moluccas and Batavia where the crew could get drunk on arack at eight pence a gallon. The Dutch, and officials of the East India Company, were suspicious, unco-operative and jealous of the rich spoils in the holds of the two British privateers and their prizes the Batchelor and Marquis. The latter was found to be too unseaworthy to proceed to Europe, and was sold to Captain John Opie, Commander of the Oley frigate in the service of the East India Company for 575 Dutch dollars. Woodes Rogers ${ }^{8}$ described the sale as "an extraordinary Bargain". "We had been offer'd much more before by another Person", he wrote, "but then I could not prevail with the majority of our Council to consent to the Sale". Dover and Opie had become firm friends; and on his return to England, he married Dover's younger daughter, Elizabeth. Realizing that the East India Company might endeavour to confiscate the whole of their hard-won spoils, Dover decided, through Opie, to warn the Bristol owners, and get them to intercede with the Queen and the Attorney General. Opie sailed direct to London, but for better security, the privateers joined a slow Dutch convoy which reached Texel in Holland in 1711 .

Their troubles were not yet over: indeed from a financial point of view they had just begun. As Dover had expected, the powerful East India Company accused them of trading in territorial waters over which they claimed a monopoly. Prolonged negotiations ended in a farcical anticlimax when East India Company agents "captured" the docked ships in London, by throwing on board acquisition notes stating: "We seize the ships and all goods aboard for the use and on behalf of the United Company of Merchants of England and the East Indies". In the final settlement the Bristol owners paid the East India Company $£ 6,000$. Dover played a leading part in these negotiations which were reported by Lord John Drummond, British Consul in Brussels and a friend of Robert Harley, leader of the Tory Government. In Drummond's letter to Harley, Dover was described as "the man of sense and conduct in all that affair". ${ }^{9}$ At that time Harley was particularly interested in gaining first-hand information as to the potentialities of the Spanish Americas, and a few months after the return of the Bristol privateers in September 1711, he pushed a bill through Parliament for "setting up the Company of Merchants of Great Britain trading to the South Sea and other parts of South America". It is almost certain that Harley and the directors of the South Sea Company sought the advice of the Bristol privateers as to their prospects of exploiting the wealth of the Spanish Empire, and it is likely that Dover, having already been favourably recommended to Harley, would be the one whose opinion was sought. The Woodes Rogers expedition had engaged an interpreter who had travelled overland from Buenos Aires to join them on the west coast of South America. Undoubtedly Dover gained some first-hand information on the commercial potentialities of the countries of the River Plate from him. At all events, Dover had every confidence in the South Sea Company, as into that unprosperous venture he put the bulk of his share of the profits of the expedition, amounting to $£ 6,689$. The Tory Government had long been vexed by large sums of money spent by the East India Company on its parliamentary nominees who wielded their influence in the Whig cause; and they were equally concerned about restoring public credit, following losses incurred by continental wars. Hence, the group of merchants forming the South Sea Company were sponsored by the 


\section{Thomas Dover and the South Sea Company}

Government, and in return for taking over the national debt of $£ 10,000,000$ for a certain period they were promised an interest rate of six per cent. Thus the South Sea Company was virtually the government banker, or at any rate in competition with the Bank of England for this privilege. But a more grandiose commercial objective was to gain a trading monopoly to export slaves and British goods to the Eastern seaboard of South America and import hides, quinine, tallow and untold wealth from the allegedly inexhaustible gold and silver mines of Mexico and Peru. In 1713 the Peace of Utrecht gave Harley an opportunity of exploiting the commercial potentialities of the Spanish Americas at the expense of the French. The Asiento Treaty, signed in Madrid on 26 March 1713, was one of the conditions of the peace settlement which transferred the South American concessions of the French Guinea Company to the British South Sea Company. The treaty came into effect on 1 May $1713^{10}$ and was to last for thirty years: it was agreed that the South Sea Company should take over trading posts and Negro slaves at Buenos Aires, Vera Cruz and Carthagena. Under the terms of the treaty 4,000 slaves per annum could be taken into Spanish America, of whom 1,200 were destined for the countries of the River Plate -800 for Buenos Aires itself and 400 for neighbouring countries. Trade was to be strictly limited to two British ships not exceeding 600 tons annually, bringing a cargo of British goods to the three trading posts or "factories". Some land for cultivation around each trading post was ceded to the South Sea Company in order to sustain the slaves. In theory the South Sea Company seemed to be a potentially prosperous venture: it provided export markets in West Africa and South America for British goods, and offered a steady supply of cheap labour for the preparation of such imports as hides, quinine and tallow. Slaves were sold for $33 \frac{1}{3}$ pieces-of-eight (escudos) providing they met the "regular standard of seven quarters not being old or defective". ${ }^{11}$ But the Spanish disliked the implementation of the treaty which usurped their monopoly: they also had a morbid fear that the British trading posts would be used as centres of intrigue and spying. They correctly foresaw, and disliked the fact, that in order to smuggle excessive goods into South America, Spanish officers would be bribed and corrupted. The Spanish authorities were also worried about the excessive slaughter of wild cattle in the countries of the River Plate in order to satisfy the British demand for hides.

The South Sea Company chartered two warships H.M.S. Anglesea and H.M.S. Warwick to take personnel and supplies ${ }^{12}$ to their trading posts. While they were being fitted out for an eight-month voyage, the Company announced an election of chief officers for their overseas factories, and on 3 September 1714, Dr. Thomas Dover headed the poll and was appointed President at Buenos Aires. ${ }^{13}$ It was decided that Dover, together with his five "factors", should proceed there aboard H.M.S. Warwick under the command of Captain Henry Partington R.N., who was destined to play an important part in his subsequent misfortunes. Partington ${ }^{14}$ had served in the Navy for nearly twenty-five years, but his career may be described as plodding rather than brilliant. Joining soon after the Glorious Revolution of 1689 , he had been promoted Lieutenant in 1693, and served as third lieutenant on the seventy-gun Stirling Castle. He probably held other appointments before joining H.M.S. Greenwick a fourth-rate in 1702. His first command was that of the fifth-rate fireship Harman on 12 October 1702, lasting for one year, when he was transferred to the 600-ton Anglesea, a forty- 


\section{Kerneth Dewhurst and Rex Doublet}

eight-gun fourth-rate. We know from subsequent events that Partington was shorttempered, a strict disciplinarian and possibly a paederast. Dover, for his part, was irascible, autocratic and strongly resented taking orders from anyone. Having commanded his own ship, he probably rated his knowledge of seamanship and navigation as being at least equal to that of Partington.

Dover's salary as first president of the Buenos Aires factory was $£ 1,000$ per annum paid in quarterly instalments to his daughter Elizabeth Opie to whom he had granted power of attorney. ${ }^{15} \mathrm{He}$ was given a gratuity of $£ 25,{ }^{16}$ together with 1,000 dollars expenses "for which he is to give an account" to enable him to take over the stores, slaves and buildings from the French Guinea Company. It was also agreed that Dover and his party could take Negro servants "not exceeding ten"17 at their own expense. But he soon came into conflict with the directors over medical supplies. As a surgeon had been appointed, Dover's role was commercial rather than medical, and the directors declined to endorse his proposed list of medicines. ${ }^{18}$

Loading and victualling of the two ships at Long Reach was subject to constant delays and changes of plan. The first lieutenant's log shows that loading began on 11 July 1713 when thirty-five tons were taken on board the Warwick, and next day another ninety-five tons were loaded. Then came a long period of inactivity until 12 November 1713 when eight cases and seven bales of South Sea goods were taken on board. ${ }^{19} \mathrm{It}$ was about this time that a shady attempt to indulge in private trading at the company's expense was uncovered. The culprit was none other than Arthur Moore, a Commissioner for Trade, friend and financial adviser to Bolingbroke, who was accused of smuggling additional cargo on board for which he was found guilty of a breach of trust and voted incapable of serving the company in the future. ${ }^{20}$ Smuggling, bribery and other corrupt practices were to bedevil the whole of the South Sea venture.

Although the crew of the Warwick had been reduced to 150 , there were still problems of space, so Partington requested the discharge of South Sea goods. ${ }^{21}$ On 8 August 1714 he was informed that no further goods should be loaded or discharged, but eleven days later he was told to transfer cargo to the Elizabeth and Bedford. ${ }^{22}$ Dover took advantage of these delays to settle his affairs in the country, and was granted ten days' leave on 13 October $1714 .{ }^{23}$ Finally all factors were told to be on board by 25 November $1714^{24}$ although the Warwick did not sail until 1 February 1715.25

The voyage got off to a bad start with a bitter quarrel as a result of which Dover, and his deputy, Richard Martin, officially complained of Partington's ill usage and general lack of co-operation. ${ }^{26}$ Their protest was supported by the South Sea Company ${ }^{27}$ which requested their Lordships of the Admiralty "to order Capt. Partington in such manner as he shall not dare to disobey them. That he not only useth our factors well, with respect and suffer them to dispose what things they have at the Madeira for the purchase of wine for their support during and after the voyage; but also when he is arrived at Buenos Ayres, he lay his ship as near the place they are to erect there". This firm letter caused the Admiralty to issue further instructions to Partington with copies to Dover and Martin which reached them in Plymouth. In a spirited defence of his actions Partington ${ }^{28}$ mentioned that he had been instructed to take six factors 


\title{
Thomas Dover and the South Sea Company
}

and ten Negro servants to Buenos Aires, whereas Dover and Martin had clandestinely brought on board five white women and four men including Martin's son. In so doing they had contravened the terms of the Asiento agreement which stipulated that the total number of Europeans at each factory should not exceed six. Furthermore he maintained that the factors had put extra goods on board; and as regards the charge of being rude or "ill-using" the factors, Partington mentioned that he had allowed them his own cabin. Finally he enclosed the following letter ${ }^{29}$ received while at Deal from the secretary to the Admiralty, which he suspected had been opened and altered in parts by Mr. Martin.

\begin{abstract}
SR
I have this night been with some Gentlemen who are employed by the Company and take their passage in the ship you command. They have some servants and other persons to proceed with them, more than mentioned in your orders from my Lords of the Admiralty which you think you are not empowered to receive. I doe assure you that it is the intention of their Lordships that you should carry all persons that may be for the Company's service, they paying for the charges of Provisions and therefore I desire you will comply with what the Gentlemen who are going over with you desire in those terms, and you may depend on it that with their Lordships' approbation.
\end{abstract}

\author{
I am, \\ Your very humble servant \\ Jos Burchett.
}

The persons that I thus recommend to you for passage are imployed in the service of the Company and will be no charge to the King.

The following postscript by Partington reflects the bitterness engendered by the quarrel. "I send you inclosed your letter to me in the Downes which do believe the raceing out some part was done by Mr. Martin which I refer to you and my reasons in my letter of this days date to their Lordships". One of the unauthorized passengers was William Toller, an educated man with a knowledge of medicine and foreign languages, whom Dover had invited as the expedition's historian. In his diary Toller ${ }^{30}$ recorded his acceptance of Dover's offer. "I going upon a profitable invitation under the President of the English factory to be settled on the Rio de la Plata for the S. Sea Comp. of Great Britain whose commands were to inform myself of every particular necessary for the said service. So to him [Dover] the world principally owes what benefit possibly may accrue from the said service". The row was finally decided in the factors' favour and the Warwick sailed from Plymouth on 17 February 1715 with Dover's black servants, his historian, secretaries, maids and possibly his concubines. ${ }^{31}$ He was fifty-three years old, and on the threshold of a new career.

The voyage to Madeira, across the South Atlantic to the estuary of the River Plate, was uneventful, and on 12 June 1715 the Warwick anchored in Castillos Bay. A longboat, escorted by armed sailors, was sent ashore in search of water: they returned safely without seeing any signs of human habitation "only wild cattle and fowl in equal numbers", so that the ship's larder was replenished with fresh fish and the meat of seven bulls. ${ }^{32}$ An excellent shot, Dover was largely responsible for these successful hunting expeditions, but when returning from his last trip ashore a strong breeze sprang up and he badly sprained his ankle when jumping into the ship's 


\section{Kenneth Dewhurst and Rex Doublet}

boat. ${ }^{33}$ Partington's charts of the River Plate were somewhat inaccurate and progress was slow to Montevideo where they arrived on 23 June 1715. Three days later two factors and six stout oarsmen were sent off in the ship's boat for Buenos Aires. Partington found difficulty in navigating out of Montevideo and ran into shallow water off the south bank, so he returned on 11 July: three days later the Warwick was fifteen miles off Montevideo, and on 23 July nine miles off Santa Lucia. ${ }^{34}$ As no pilots had arrived by 5 August, Dover called a conference of the factors at which it was decided to ask Partington to make arrangements for them all to go to Buenos Aires in the ship's boats: it was imperative that they should get there before the expected ship-load of slaves arrived. On 14 August Dover, his associates and their servants, set out on the 140 miles' voyage to Buenos Aires in the ship's yawl and longboat, ${ }^{35}$ and after their safe arrival they sent back a yawl and a brigantine with two Spanish pilots and customs officers. Next day cargo transferred from the Warwick to the brigantine included 1169 oak boards and 1032 deal boards urgently needed to build warehouses and provide accommodation for slaves. ${ }^{36}$ Finally the Warwick arrived in Buenos Aires on 11 September 1715.37

Meanwhile Dover had been establishing good relations with the Spanish authorities. He had called on the Governor, the Bishop and the head of the Jesuit College. Though a Protestant and living in an intolerant age, Dover had made every endeavour to show respect to those of the Roman Catholic faith. During his previous voyage he had participated in a Roman Catholic service, and again showed himself to be a skilful negotiator in spite of his irascible temper. After taking over the French property together with some hides and twenty-two Negro slaves, Dover found that he had spent the 1,000 dollars allowed him for incidental expenses, so he turned to the Jesuits for help. After listening to his financial problems, Father Herran asked Dover the amount he required, and such was the measure of trust between them that his request for 150,000 pesos was met the next morning. Dover then began extending his "factory", situated near the present Plaza de San Martin, which comprised warehouses, offices, homes for the factors and "barracoons", to accommodate the slaves. More ships began to arrive and by the end of 1715, five slaving ships had anchored off Buenos Aires including the Indian Queen with 100 cases of smallpox on board. ${ }^{38}$ Dover instituted Sydenham's "cooling" regimen with excellent results, but the epidemic greatly reduced his medical supplies, and he urgently requested that various "medicines may be sent by the first opportunity". ${ }^{39}$ At the beginning of January 1716, hides were loaded aboard H.M.S. Warwick, 900 on 3 January and 1980 several days later, ${ }^{40}$ but between 23 and 28 February 5324 hides were transferred from the Warwick surreptitiously to two chartered merchantmen. ${ }^{41}$ Thus the treaty was circumvented; and conversely when cargoes arrived from Britain they were unloaded in full view of the Spanish officers, but later behind their backs (or with their benevolent connivance), warehouses were filled to capacity with unauthorized goods.

The slave trade from Africa to South America went back to the time of the Spanish conquest. Between 1597-1680, 22,892 slaves were imported into the River Plate, and during the French concession between 1708-1712, 3,475 slaves had been brought from Africa to Buenos Aires. The South Sea Company's ${ }^{42}$ instructions to the captain 


\section{Thomas Dover and the South Sea Company}

of one of their chartered merchantmen, the Asiento, gives new details of this unsavoury trade. He was ordered to take merchandise to Angola, sell it to the best advantage, and purchase 375 Negroes between the ages of ten and thirty years in approximately equal numbers of males and females. Surplus money was to be invested in gold and ivory. Copies of all purchases were to be sent to Buenos Aires and London. On arrival at Buenos Aires the captain was ordered to discharge the Negroes, and fill his holds to capacity with hides. As an inducement to take care of the slaves, and to prevent frauds, captains were "given" four Negroes for every 104 arriving healthy in Buenos Aires. During the voyage Negroes were to be mustered every fourteen days and records kept of any deaths. Before dead bodies were thrown overboard the surgeon and chief mate were to record the number, date and cause of death; and the captain could not be paid his commission nor the surgeon given his "head money" until they had sworn on oath that the number of dead and those delivered alive had been correctly recorded. To preserve the health of slaves during the long voyage the ship's decks were to be washed with water and vinegar in order to ward off infections. The company also appreciated the psychological trauma associated with uprooting simple pastoral people from their homeland and transporting them in overcrowded ships to another continent, and captains were instructed to "divert them with musick and play". On arrival at Buenos Aires, ships were loaded to capacity with hides and "Tallow paraguay". It was stressed that ships' officers were not under any circumstances permitted to indulge in private trade; and they were warned not to give "any scandal to those of the Roman Catholick Religion". Apart from 1,000 slaves transported to Buenos Aires from Madagascar in $1716^{43}$ most of the slaves came from West Africa; and during the Asiento agreement nearly 10,000 were taken to Buenos Aires.

Trade at Buenos Aires, though pursued with somewhat unorthodox methods, was flourishing. Building of the factory had now been completed; and on 7 April 1716 the Prince of Wales and the Indian Queen sailed for London with a capacity cargo of hides. ${ }^{44}$ Though at anchor in a foreign port, the proprieties of naval routine were observed, as on the birthdays of the Prince and Princess of Wales, the Warwick fired seventeen- and fifteen-gun salutes respectively, and a twenty-one-gun salute on Coronation Day. ${ }^{45}$ Having now completed her mission, H.M.S. Warwick sailed for home on 9 June 1716 with a cargo of 11,215 hides. ${ }^{46}$ But in spite of the huge export of hides and imports of slaves into the River Plate, the directors of the South Sea Company were dissatisfied with Dover's irregular handling of their affairs. They had now received first-hand information about the state of the Buenos Aires trading post from four ships returning to London, and on 30 April 1716 a letter from Captain Partington was read and discussed. ${ }^{47}$ Although its contents are unknown it is fairly certain that Dover's activities were cast in an unfavourable light. However, the directors sought more information before reaching a decision, and on 6 June 1716 they invited M. Edme, formerly President of the French factory at Buenos Aires, to dine with them so as to get "an opportunity of discoursing him relating to the Trade at that place". ${ }^{88}$ They also set up a special committee "to compare the Instructions with the Actions of the Buenos Aires Factory", 49 and it was decided that within one week "the state of the Factory will be considered without delay". A decision was reached on 18 July 1716 when this minute was recorded:50 


\section{Kenneth Dewhurst and Rex Doublet}

The Court took into Consideration the State of the Buenos Ayres Factory, according to the order of the last Court, and after some debate resolved that Captain Dover President of the said Factory for Breach of his Instructions and neglect of Duty, be dismissed from the service of the Company.

It was also agreed that the other factors be continued in the company's service with the exception of the surgeon Mr. Philips who was to be the subject of further enquiries. John Thrupp was appointed Dover's successor at a salary of 4,000 pieces-of-eight per annum. Why was Dover dismissed? His congenital dislike of taking orders, least of all from the chairborne directors of the South Sea Company, the majority of whom had never left the shores of Britain, would not have endeared him to his superiors. But his rebellious nature was not the sole cause of his sacking. Irascible, independent and dogmatic, Dover had never worked well in harness. The directors regarded private trading as the most serious offence; and a company warrant issued to Dover's daughter for the sum of $£ 810 s$. 11d. with this note: "Paraguay in Private Trade" 51 shows that he had contravened their regulations. This is only a trivial amount, but indirect evidence shows that in partnership with his son-in-law, Captain John Opie, Dover had indulged in private trade on a larger scale, and ten years later Opie was also dismissed from the company's service. We also know that Dover was bribing Spanish officials, as on 17 November 1716 a bill was submitted by him for the sum of $£ 3892 s .11 \frac{1}{2} d$. "for presents made to the Royal Officers". ${ }^{52}$ Bribery was then a routine commercial practice, and although the directors had grounds for suspicion, Dover had probably acted in good faith in order to boost the Company's profits. But Spanish sources ${ }^{53}$ reveal that Dover was taking a commission on the purchase of hides; and he might well have been involved in submitting inflated claims for the medical care and maintenance of slaves, as his surgeon William Philips was under suspicion.

Although Dover had been dismissed in July 1716, it took several months for the news to reach him, and longer for his replacement to arrive. Meanwhile he continued to draw his salary in quarterly instalments. ${ }^{54}$ In London Dover's successor prepared to leave and sought the company's permission to take a "housekeeper to the Factory" and a "Secretary or Book-Keeper" which the directors rejected outright and allowed only "one menial servant" as they had no intention of sending out another president in the grand manner..$^{55}$

Captain Partington now arrived home after an uneventful voyage, apart from a quarrel with his second lieutenant whom he logged on 7 October 1716, nineteen days before reaching Woolwich. ${ }^{56}$ But his troubles had just begun, as his ship's surgeon had laid official complaints against him which led to his court martial. Here is the official account of the proceedings: ${ }^{57}$

At a Court Martiall held on board His Majesty Shippe Orford att Sheernesse on Thursday the 29th of November 1716.

Present

Sir Charles Wager, Knt. Vice Admiral of the Blew Squadron of his Majesties Fleet etc President, Capts. John Balchew, Edw Holland, Phillip Cavendish, J. Stuart, Thos Scott, George Gordon, Thos Kempshorne, Thos Jacob, George Saunders, Thos Smart Pearce.

The Court proceeded to the Tryal of Capt Henry Partington, late Captain of HM ship Warwick, upon several articles exhibited in a complaint made against him by Robert Rootsoy late surgeon 


\section{Thomas Dover and the South Sea Company}

of the said Ship of several irregularities committed by him in his last voyage to the South Seas and having examined the evidence upon etc. Captain Partington had been irregular in permitting his Purser to Victuall the Ship with beefe at a very low price and excusing him from victualling with bread which was at a high price to the prejudice of the King and that the Captain received from the said purser a present of wine and a piece of Plate, and also punishing Robt. Lumarale and others beyond and contrary to rules and histories of the Navy. Fined six months pay due for service in Warwick to be applied to the use of the Check at Chatham. And as to other charges appeared to be trifling and not fully proved, he is acquitted.

One charge concerned the gift of a cask of brandy: the other, of more sinister import, was that of employing two boys, Moor and Wild aged eleven and twelve years, as servants. But the chaplain spoke well of him, and the last two charges were dropped. This was the end of Partington's naval career: he never held another command and remained on half pay until his death in 1737. A few months later, on 24 February 1717, Thrupp's arrival in Buenos Aires, ${ }^{58}$ marked the end of Dover's career with the South Sea Company. He probably returned to England on the same ship, and before the end of the year, was practising medicine from Cecil Street, Strand, where he successfully treated Bolingbroke's coachman for the gout. ${ }^{59}$

The London of Dover's time was shaped rather like a dumbbell, with the cities of London and Westminster at either end, and the Strand between. Cecil Street was therefore equally well placed for professional visits to Westminster, or business deals in the City, which was then at the height of speculation fever. As a substantial shareholder in the South Sea Company, Dover would be a frequent visitor to Exchange Alley, as his practice at that time was probably quite small. But enterprise, like Icarus, had soared too high. The South Sea Company had paid out bribes of $£ 1,250,000$ to public men in order to bolster confidence, but against the premiums they had issued unsanctioned stock. The crash came in 1720. Robert Knight the treasurer absconded with "considerable Effects" but was "stop'd and secur'd in Flanders" having left assets in Britain valued at $£ 36,000$. 60

Dover's heavy losses now caused him to turn to medicine where his services were increasingly in demand during a smallpox epidemic: his successful though unorthodox treatment brought him to the notice of people of rank and fortune. Viscountess Dupplin, ${ }^{61}$ writing to her aunt Abigail Harley, Countess of Oxford, described Dover as "a famous man who undertakes to cure smallpox a new way". She mentioned that his patients included the Duchess of Richmond, Lady Mildred Hotham, Lady Louisa Berkeley and the Duchess of Devonshire who "turned off Mead and Freind, and sent for him to Lady Rachel Manners". Dover's outstanding success at the expense of the most eminent London physicians is confirmed in another letter ${ }^{62}$ from the Reverend Thomas Mangey (chaplain to the Bishop of London) to Dr. Waller. He mentioned that Dover's professional skill was now "the whole talk of the town". "One Dr. Dover, a man unknown to the faculty", he continued, "and who hath been a Sea captain for many years", had greatly diminished the reputation of the fashionable physicians. Mangey then mentioned a smallpox patient whose prognosis, according to Mead, was hopeless, yet Dover saved her life by adopting Sydenham's "cooling" regimen. "He declaims against his brethren of the faculty with public and great vehemence", he wrote, "and particularly against purging and blistering in the distemper which he affirms to be the death of thousands". In the light 


\section{Kenneth Dewhurst and Rex Doublet}

of modern knowledge Dover's "cooling" treatment had a more rational basis than those of the orthodox physicians, as thereby dehydration was corrected, the temperature reduced, haemoconcentration was countered by bleeding and copious fluids, and the intense skin irritation was eased. On the other hand, Dover's arrogant and forthright condemnation of the practice of others aroused professional hostility to which he was highly vulnerable, as not being a licentiate of the College of Physicians he was not legally entitled to practise in London. Heavy losses on the stock exchange now precipitated a return to medicine in earnest, so throughout 1721 Dover was occupied with monthly examinations until he was admitted licentiate of the College of Physicians in September. ${ }^{63}$ He was then sixty years old, but the passage of time had not diminished his rumbustious nature, as in February 1722, barely five months after his admission, Dover appeared before the college for having transgressed their moral statutes. ${ }^{64}$ He was alleged to have refused to meet in consultation a colleague who had applied blisters which Dover immediately ripped off. Blistering was one of Dover's strongest aversions. "An eminent physician when asked how blistering came so much a fashion, he answered they had it from the Indians." "But I", Dover, with a characteristic flourish, "that have seen more Indians than all the physicians in England, deny that the Indians ever make use of blisters". Dover maintained that blisters tended to draw off the serum, which he considered to be "the purest part of the blood", and they also caused unnecessary pain, a point of view supported by Radcliffe and Sydenham. Undoubtedly there was an element of professional jealousy behind this complaint, as Dover was merely admonished by his friend Sir Hans Sloane, the President, with whom he afterwards continued to be on good terms. Nevertheless this reverse became coffee-house gossip and together with his earlier criticisms of the apothecaries' excessive profits adversely affected his practice, which had started so well, and now, like his investments, began to dwindle away. In 1726 he returned to Barton-on-the-Heath, where his wife died. Dover was now plagued by creditors, as he had mortgaged his farms to buy South Sea stock, and in May 1727 he was forced to sell his lands to Thomas Mander of the Inner Temple for $£ 3,400$. Mander agreed to an immediate payment of Dover's debts, including $£ 800$ to the South Sea Company, and to discharge a mortgage of $£ 1,037$ 10s. 0 d.: when all his debts had been paid Dover received only $£ 140$ until the balance of $£ 1,56210$ s. was due on 29 September $1727 .{ }^{66}$

Widowed, homeless and virtually bankrupt, Thomas Dover had now reached the nadir of his chequered career. He went to live with his kinsman, Robert Tracy, at Stanway Hall in Gloucestershire where his professional services were soon in demand, as a severe epidemic lasting two years swept "off whole families, nay almost whole villages". ${ }^{67}$ After two years in Gloucestershire, he moved to Bristol, and when trying to establish a practice Dover solicited patients from Sir Hans Sloane. ${ }^{68}$ They were slow to come so he began writing a popular medical book; and in 1732 when The ancient physician's legacy was published Thomas Dover at the age of seventy was practising from Lombard Street, ${ }^{69}$ and again poised for a conquest of the capital. His book was a sort of eighteenth-century Family physician: it "made a great noise in London and was the subject of almost every coffee house". ${ }^{70}$ It is, of course, best known for this powder which still bears his name. 


\section{Thomas Dover and the South Sea Company}

Take Opium one ounce, Salt-Petre and Tartar vitriolated each four ounces, Ipecacuanha one ounce, Liquorish one ounce. Put the Salt-Petre and Tartar into a red hot mortar, stirring them with a spoon until they have done flaming. Then powder them very fine; after that slice in your opium, grind them to a powder, and then mix the other powders with these. Dose from forty to seventy grains in a glass of white wine Posset going to bed; covering up warm and drinking a quart or three pints of the Posset-Drink while sweating. ${ }^{\text {11 }}$

Another prominent feature of Dover's book was his constant advocacy of crude mercury which earned him the title of the "Quicksilver Doctor". The quicksilver controversy triggered off a pamphlet war lasting for fifty years, and like Montgolfier's balloon, owed its bouyancy to a steady release of hot air. Dover's book seemed to have revived his practice, as in $\mathbf{1 7 3 6}$ he moved westwards to a more fashionable address in Arundel Street but continued to consult his apothecaries at the Jerusalem Coffee House in the Strand. During his declining years he was not only busy with his practice but found time to answer his critics in successive editions of his Legacy wherein he mounted simultaneous attacks against the College of Physicians and the Society of Apothecaries. Dover was eighty years old in 1742 when the sixth edition of his Legacy appeared. He retired to spend his last days with the Tracys at Stanway Hall, and was buried in the vault of the Tracy family at Stanway Church on 27 April 1742. Some eighty years ago, restoration obliterated Dover's only memorial: this is less than his memory deserves, and Sir William Osler, who described him as a "bluff, hearty headstrong Englishman with many likeable qualities", ${ }^{72}$ was about to erect a memorial tablet when the outbreak of the First World War put an end to this scheme.

\section{REFERENCES}

1. Sir William Osler, 'Thomas Dover, physician and buccaneer', Johns Hopk. Hosp. Bull., 1896, 7: 1 .

2. L. Eloesser, 'Pirate and buccaneer doctors', Ann. med. Hist., 1926, 8: 31.

3. L. Dopson, 'Thomas Dover: pirate and physician', Warw. J., 1947, 2: 214.

4. J. A. Nixon, 'Thomas Dover, physician and merchant adventurer', Bristol Med.-chir. J., 1909, 27: 31.

5. The summary is based on Kenneth Dewhurst's, The quicksilver doctor, Bristol, John Wright \& Sons, 1957.

6. Records of the High Court of Admiralty, 1704. Declaration of Letters of Marque $26 / 13$, fol. 66d.

7. Woodes Rogers, A cruising voyage round the world, London, Cassell, 1928, p. 91. (1st ed., London, A. Bell, 1712).

8. Ibid., pp. 293-294.

9. Letter from J. Drummond to the Earl of Oxford, August 1711, Harley Papers, vol. 34, f. 1926.

10. John Morphew, Some consideration relating to the management of the affairs of the South Sea Company, London, 1716.

11. Anon., A true and impartial account of the rise and progress of the South Sea Company, London, 1743.

12. MSS. Add. 25. 495 Minutes of South Sea Company, 22 October 1712, f. 15 (British Museum).

13. Ibid., 3 September 1714, f. 401.

14. J. Charnock, Biographia navalis, London, Faulder, 1795, vol. 3, p. 277.

15. MSS Add. 25. 445. 17 November 1714, f. 458 (British Museum). 


\section{Kenneth Dewhurst and Rex Doublet}

16. Ibid., f. 459.

17. MSS Add. 25/495, f. 217.

18. MSS Add. 25, 445, 29 September 1714, p. 414; 13 October 1714, p. 429 and p. 440.

19. First Lieutenant's Log H.M.S. Warwick, 1713-1716, ADM 4388 11-12 July 1713 and 12 November 1713 (National Maritime Museum, Greenwich).

20. E. Erlington Ball (ed.), The correspondence of Jonathan Swift, London, G. Bell \& Sons, 1911, vol. 2, p. 176; and Add. MSS 25 495, ff. 166-183, Minutes of South Sea Co., 16-29 June 1714 (British Museum).

21. Captain's Letters, H.M.S. Warwick, 27 June 1714, P.R.O. ADM: 1/2281.

22. Ibid., 19 August 1714.

23. MSS Add. 25. 49513 October 1714, p. 427.

24. MSS Add. 25. 445, 12 November 1714, p. 449.

25. First Lieutenant's Log H.M.S. Warwick, 1713-1716, op. cit., 1 February 1715.

26. MSS Ad. 25/496, 9 February 1715, p. 2.

27. MSS Add. 25/559 South Sea Co. Orders, Warrants etc. 9 February 1715, f. 45.

28. Captain's Letters, op. cit. (ref. 21), 16 February 1715.

29. Ibid., 30 July 1714.

30. MSS Diary entitled: 'The history of a voyage to the River Plate and Buenos Ayres from England. Anno MDCCXV' by William Toller (National Library, Madrid).

31. Master's Log, H.M.S. Warwick, 1713-1716, P.R.O. ADM. 52/314, 17 January 1715.

32. Captain's Log, H.M.S. Warwick, 1713-1716, P.R.O. ADM 51/1072, 12 June 1715.

33. William Toller, op. cit. (ref. 30).

34. Ibid., 14 and 23 July 1715.

35. Ibid., 5 August 1715.

36. Ibid., 19 August 1715.

37. Ibid., 11 September 1715.

38. Captain's Log, op. cit. (ref. 32), 27 October 1715.

39. MSS Add. 25/496, 20 April 1716, p. 111.

40. MSS Add. 25/495, 27 October 1714, p. 432; and Captain's Letters, op. cit. (ref. 21), 3 January 1716.

41. Captain's Log, op. cit. (ref. 32), 3 January 1716 to 28 February 1716.

42. B.M. MSS Add. 25/567, pp. pp. 34-39, November 1723.

43. B.M. Add. 25/497, pp. 8-54, 16 January 1717.

44. Captain's Log, op. cit. (ref. 32), 7 April 1716.

45. Ibid., 20 October 1716; 21 October 1716; 30 October 1716.

46. Ibid., 9 June 1716.

47. B.M. Add. 25/496, vol. 3, p. 126, June 1716.

48. Ibid., 6 July 1716, p. 272.

49. Ibid., 12 July 1716, p. 276.

50. Ibid., 18 July 1716, p. 296.

51. Ibid., 12 December 1716, p. 357.

52. Ibid., 31 October 1716, p. 341.

53. Cabildo Minutes (Buenos Aires) for March and August 1716 refer to disorders within the company to the detriment of the shareholders.

54. B.M. Add. 25/496, 31 October 1716, p. 341.

55. Ibid., 14 November 1716, p. 346.

56. Captain's Letters, op. cit. (ref. 21), 7 October 1716.

57. ADM 1/5271, 29 November 1716, National Maritime Museum.

58. B.M. MSS Add. 25/496, 24 February 1717.

59. Thomas Dover, The ancient physician's legacy etc., 6th ed., London, A. Bellesworth \& C. Hitch \& R. Minors, 1742, p. 12.

60. B.M. Add. 25/60, South Sea Company Petitions etc. (1720/1729), p. 2.

61. Letters from Viscountess Dupplin to Countess of Oxford, 4 March 1720. Harley Papers, vol. 34, ff. 192a and b. 
Thomas Dover and the South Sea Company

62. John Nichols, Literary anecdotes of the eighteenth century, London, Nichols and Bentley, 1812, vol. 1, p. 534.

63. Ann. R. Coll. Physns., 1721, 8: 154 (5 May), 175 (30 September).

64. Ibid., 8: 200 (5 January 1722).

65. Thomas Dover, op. cit., p. 105.

66. Indenture between Thomas Dover and Thomas Mander, 6 May 1727, (Royal College of Surgeons Library).

67. Thomas Dover, op. cit., p. 144.

68. B.M. Sloane MSS 4046, f. 80; 4051, f. 225; 4058, ff. $264-5$.

69. Thomas Dover, op. cit., p. 201.

70. Ibid., p. 39.

71. Ibid., p. 14.

72. Sir William Osler, op. cit., p. 6. 